\title{
Constraints Perceived By Beneficiaries of Livestock Based Self Help Groups (SHGs)
}

\author{
Akshita Chadda*, Y.S. Jadoun, S.K. Kansal, H.K. Verma and Bharti \\ Department of Veterinary \& Animal Husbandry Extension Education, Guru Angad Dev \\ Veterinary and Animal Sciences University (GADVASU), Ludhiana, Punjab, India \\ *Corresponding author
}

\begin{tabular}{|l|}
\hline Ke y w o r d s \\
$\begin{array}{l}\text { Livestock, Self help } \\
\text { groups, Technical, } \\
\text { Socio- } \\
\text { psychological, } \\
\text { Marketing }\end{array}$ \\
\hline Article Info \\
\hline $\begin{array}{l}\text { Accepted: } \\
\text { 20 June 2019 } \\
\text { Available Online: } \\
\text { 10 July } 2019\end{array}$ \\
\hline
\end{tabular}

\section{Introduction}

Punjab is one of the leading livestock producing state where livestock activity is increasingly more commercialized and market driven enterprise. However livestock rearing

\section{A B S T R A C T}

The present study was conducted in Ludhiana district of Punjab to identify the constraints perceived by beneficiaries of livestock based Self Help Groups (SHGs). Data were collected using structured interview schedule from 120 women beneficiaries of the livestock based SHGs. Garrett's ranking technique was used to prioritize the different sets of constraints in terms of their mean score. Findings of the study regarding constraints perceived by beneficiaries of livestock based Self Help Groups (SHGs) revealed that, "beneficiaries were not getting proper price of milk (63.40)" and "lack of proper knowledge about purchase of good quantity of feed, fodder and milch animals (53.58)" were the major general constraints in order of severity. Under training oriented constraints; "lack of trained, field oriented and experienced staff at village level (57.64)" was the most severe. "Lack of proper technical guidance and advice (65.23)" Inadequate milk processing / value addition (56.41)" and "veterinary staff do not visit the area regularly (54.01)" were the most important technical constraints. "High cost of cattle feed and mineral mixture (56.42) was perceived as main input and service constraints. "Complicated procedures to get loan, subsidy for livestock purpose (53.10)", delay in payment of milk (52.67)" and concerned officials are not interested to visit the area and conducting regular meeting with beneficiaries were the major administrative constraints in terms of their severity. "Lack of risk bearing capacity among the members (58.83)" and "lack of participation of members with various developmental organizations (50.72)" were important socio-psychological constraints. Un-organized marketing (64.12) and lack of consumer support (63.44)" were the major severe constraints as perceived by the beneficiaries. Hence, for smooth functioning of livestock based SHGs in sustainable manner there is dire need to remove of these constraints on priority basis with the considerable focus on the need and interests of the beneficiaries. 
are problems that cannot be tackled individually and can be solved through group efforts. To address the challenge of poverty, the micro-finance, Self-Help Groups (SHGs) and credit management groups have been started in India. Today, this collective action is known as Self-Help Groups, considered the vehicle of change for the poor, mostly for marginalized women. With the small beginning as a pilot programme launched by NABARD by linking 500 SHGs with banks in 1992, the programme has reached to linking of 87.4 lakh SHGs and has covered about over 10 Crore poor Indian households as on 2018. Out of 87.4 lakh SHGs, 73.22 lakh are exclusively women SHGs. Out of total 87.4 lakh SHGs, 37.44 lakh are under NRLM. With the formation of SHGs, financially excluded, resource poor persons and weaker section of the society have been able to assess financial services from formal banking sectors.

SHG approach has been recognized as an institutional innovation to organize poor, promote saving, channelize credit; encourage income generating programmes and then empowerment of rural poor. It is known that women's participation in income generating activities is believed to increase their socio economic status and power in the society. Women through livestock based Self Help Groups have involved themselves in different types of income generating activities like dairy farming, poultry farming, piggery farming, goat farming etc. SHGs in many ways have gone beyond the means of delivering the financial services as channel and turned out to be focal point for purveying various services to the poor. Women farmers could get better returns on developing value chain through Self Help Groups (SHGs). But the success of any group / micro finance institute depends on its smooth functioning without any constraints to the beneficiaries. Hence, it was needed to take feedback of the beneficiaries regarding constraints for getting benefits from these
SHGs. The analysis of these constraints is very essential to overcome them for proper functioning of SHGs sustainably. Keeping this in view the present study was conducted to analyze various constraints viz., general, training oriented, technical, input and service, administrative, socio-psychological and marketing constraints faced by beneficiaries of livestock based SHGs.

\section{Materials and Methods}

The present study was carried out in Ludhiana district of Punjab. A multistage random sampling procedure was applied to draw the sample for the study. Ludhiana district was purposively selected based on large number of livestock based functional women Self Help Groups (SHGs). Twenty four Self Help Groups were selected randomly from the list of Self Help Groups which are successfully functioning in livestock farming activities in various villages of different blocks of Ludhiana district of Punjab. In order to find out the constraint faced by beneficiaries of SHGs, five SHG women members were selected randomly from each Self Help Group, thereby making the sample size of 120 respondents for the study.

To analyze various constraints faced by beneficiaries of SHGs, a structured interview schedule was developed under sub-heads namely, general, training oriented, technical, input and service, administrative, sociopsychological and marketing constraints. The data were collected by face to face interview using pre-tested structured schedule. Garrett's ranking technique was used to prioritize the different sets of constraints in terms of their mean score.

According to Garrett's ranking technique, the respondents were asked to enumerate and assign ranks to different constraints, which were used for prioritization of constraints. The 
orders of merit as given by the respondents were converted into ranks, by using the following formula:

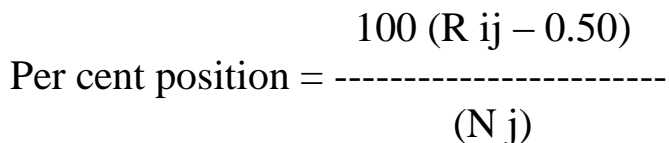

Where,

Rij = Rank given for ith problem by jth individual.

$\mathrm{Nj}=$ Number of problems ranked by the jth individual.

The percent position of each rank was then converted into scores, by referring to the table, as given by Garrett. The scores of individual respondents for a particular problem were added and divided by the total number of respondents. The mean scores for all the constraints were arranged in descending order and thus, rank were assigned to prioritize the constraints.

\section{Results and Discussion}

The constraints as faced by the beneficiaries of SHGs have been categorized and discussed under following sub-heads.

\section{General constraints}

The data presented in Table 1 , revealed that the constraint "not getting proper price of milk" (mean score: 63.40) was assigned rank first, while "lack of proper knowledge about purchase of good quantity of feed, fodder and milch animals" (mean score: 53.58) and "problem in taking group decision" (mean score: 53.08) and were ranked second and third, respectively. The present finding regarding "problem in taking group decision" is in line with the findings of Jain and Kushawala (2004).
The other constraints such as "lack of coordination and participation among members" (mean score: 52.82), "difficulty in maintaining proper record due to lack of awareness" (mean score: 45.12), "dominance of some group members" (mean score: 45.05), "lack of awareness about insurance facility of the animals" (mean score: 43.88) and "poor knowledge of beneficiaries about functioning of SHG" (mean score: 41.16) were ranked $4^{\text {th }}$, $5^{\text {th }}, 6^{\text {th }}, 7^{\text {th }}$ and $8^{\text {th }}$ respectively by the beneficiaries on the basis of their mean score.

\section{Training oriented constraints}

It could be inferred from the Table 2 that "lack of trained, field oriented and experienced staff at village level" (mean score: 57.64) was the most serious constraints perceived by the beneficiaries and it was ranked first.

Another constraints "lack of training facilities / training centers at village level" (mean score: 56.33), "lack of awareness programmes about scientific livestock farming practices (SLFP's) at village level (breeding, feeding, health care and management practices)" (mean score: 44.90) and lack of transport facility to attend training programmes at training centers (mean score: 40.13$)$ ranked $2^{\text {nd }}, 3^{\text {rd }}$ and $4^{\text {th }}$ respectively.

\section{Technical constraints}

The results presented in the Table 3 revealed that, "lack of proper technical guidance and advice" (mean score: 65.23)" was faced as most important constraint and ranked first by the beneficiaries.

"Inadequate milk processing / value addition / infrastructure facility at field level" (mean score: 56.41); and "veterinary staff do not visit the area regularly" (mean score: 54.01); were ranked second and third most important constraints as faced by the beneficiaries. 
Table.1 General constraints faced by the beneficiaries

\begin{tabular}{|c|l|c|c|}
\hline Sr. No. & \multicolumn{1}{|c|}{ Constraints } & Mean score & Rank \\
\hline 1 & Poor knowledge of beneficiaries about functioning of SHG & 41.16 & VIII \\
\hline 2 & Difficulty in maintaining proper record due to lack of awareness & 45.12 & V \\
\hline 3 & $\begin{array}{l}\text { Lack of proper knowledge about purchase of good quantity of } \\
\text { feed, fodder and milch animals }\end{array}$ & 53.58 & II \\
\hline 4 & Lack of awareness about insurance facility of the animals & 43.88 & VII \\
\hline 5 & Not getting proper price of milk & 63.40 & I \\
\hline 6 & Problem in taking group decision & 53.08 & III \\
\hline 7 & Lack of coordination and participation among members & 52.82 & IV \\
\hline 8 & Dominance of some group members & 45.05 & VI \\
\hline
\end{tabular}

Table. 2 Training oriented constraints faced by the beneficiaries

\begin{tabular}{|c|l|c|c|}
\hline Sr. No. & \multicolumn{1}{|c|}{ Constraints } & Mean score & Rank \\
\hline 1 & Lack of trained, field oriented and experienced staff at village level & 57.64 & I \\
\hline 2 & Lack of training facilities / training centers at village level & 56.33 & II \\
\hline 3 & $\begin{array}{l}\text { Lack of awareness programmes about scientific livestock farming practices } \\
\text { (SLFP's) at village level (breeding, feeding, health care and management } \\
\text { practices) }\end{array}$ & 44.90 & III \\
\hline 4 & Lack of transport facility to attend training programmes at training centers & 40.13 & IV \\
\hline
\end{tabular}

Table.3 Technical constraints faced by the beneficiaries

\begin{tabular}{|c|l|c|c|}
\hline Sr. No. & \multicolumn{1}{|c|}{ Constraints } & Mean score & Rank \\
\hline 1 & Lack of proper technical guidance and advice & 65.23 & I \\
\hline 2 & Veterinary staff do not visit the area regularly & 54.01 & III \\
\hline 3 & $\begin{array}{l}\text { There is lack of advisory / SMS services for care of animals in different } \\
\text { seasons }\end{array}$ & 49.56 & IV \\
\hline 4 & AI facilities are not available timely & 38.21 & V \\
\hline 5 & Inadequate milk processing / value addition / infrastructure facility at field level & 56.41 & II \\
\hline 6 & Poor conception rate of the animals & 37.47 & VI \\
\hline
\end{tabular}

Table.4 Input and service constraints faced by the beneficiaries

\begin{tabular}{|c|l|c|c|}
\hline Sr. No. & \multicolumn{1}{|c|}{ Constraints } & Mean score & Rank \\
\hline 1 & High cost of cattle feed and mineral mixture & 56.42 & I \\
\hline 2 & Cattle feed and fodder are not available at subsidized rate & 46.36 & IV \\
\hline 3 & High cost of veterinary medicines & 49.28 & III \\
\hline 4 & $\begin{array}{l}\text { Non availability of cheap, hybrid fodder seeds, fertilizers and } \\
\text { other material at proper time }\end{array}$ & 42.58 & V \\
\hline 5 & High charges of emergency veterinary services & 53.68 & II \\
\hline
\end{tabular}


Table.5 Administrative constraints faced by the beneficiaries

\begin{tabular}{|c|l|c|c|}
\hline Sr. No. & \multicolumn{1}{|c|}{ Constraints } & Mean score & Rank \\
\hline 1 & $\begin{array}{l}\text { Concerned officials are not interested to visit the area and } \\
\text { conducting regular meeting with beneficiaries }\end{array}$ & 50.03 & III \\
\hline 2 & Biasness in selecting beneficiaries and formation of groups & 43.71 & V \\
\hline 3 & Delay in payment of milk & 52.67 & II \\
\hline 4 & Complicated procedures to get loan, subsidy and other benefits & 53.10 & I \\
\hline 5 & Non- cooperation of bank officials & 48.38 & IV \\
\hline
\end{tabular}

Table.6 Socio psychological constraints faced by the beneficiaries

\begin{tabular}{|c|l|c|c|}
\hline Sr. No. & \multicolumn{1}{|c|}{ Constraints } & Mean score & Rank \\
\hline $\mathbf{1}$ & Lack of democratic awareness, harmony and participation among group members & 56.64 & II \\
\hline $\mathbf{2}$ & Lack of risk bearing capacity among the members & 58.83 & I \\
\hline $\mathbf{3}$ & $\begin{array}{l}\text { Resource full / progressive people of the village discouraging the members to join } \\
\text { the group }\end{array}$ & 38.25 & $\mathbf{V}$ \\
\hline $\mathbf{4}$ & Lack of participation of members with various developmental organizations & 50.72 & III \\
\hline $\mathbf{5}$ & Preference for jobs rather than dairy based self-employment & $\mathbf{4 3 . 5 3}$ & IV \\
\hline
\end{tabular}

Table.7 Marketing constraints faced by the beneficiaries

\begin{tabular}{|c|l|r|c|}
\hline Sr. No. & \multicolumn{1}{|c|}{ Constraints } & Mean score & Rank \\
\hline $\mathbf{1}$ & Lack of marketing skills & 59.73 & IV \\
\hline $\mathbf{2}$ & Lack of adequate price of the value added products & 57.15 & VI \\
\hline $\mathbf{3}$ & Lack of consumer support & 63.44 & II \\
\hline $\mathbf{4}$ & Un-organized marketing & 64.12 & I \\
\hline $\mathbf{5}$ & High packaging cost & 49.43 & VII \\
\hline $\mathbf{6}$ & Lack of advertisement & 42.93 & VIII \\
\hline $\mathbf{7}$ & Lack of government support & 40.29 & $\mathbf{X}$ \\
\hline $\mathbf{8}$ & Distant markets & 59.00 & V \\
\hline $\mathbf{9}$ & Competition among fellow SHGs & 36.61 & XI \\
\hline $\mathbf{1 0}$ & Irregular demand of product & 61.78 & III \\
\hline $\mathbf{1 1}$ & Less time available for sale of product & 40.73 & IX \\
\hline $\mathbf{1 2}$ & Insufficient knowledge regarding marketing policy & $\mathbf{2 5 . 9 2}$ & XII \\
\hline
\end{tabular}

The other constraints includes, "lack of advisory / SMS services for care of animals in different seasons" (mean score: 49.56); "AI facilities are not available timely" (mean score: 38.21 ), "poor conception rate of the animals" (mean score: 37.47 ) were ranked as $4^{\text {th }}, 5^{\text {th }}$ and $6^{\text {th }}$ respectively by the beneficiaries on the basis of their mean score among the various technical constraints.

\section{Input and service constraints}

It could be observed from the Table 4 that "High cost of cattle feed and mineral mixture" (mean score: 56.42); was ranked first as the most serious constraint faced by the beneficiaries, which is supported by the findings of Varathan et al., (2012). The second most serious constraint was "high charges of 
emergency veterinary services" (mean score: 53.68); followed by "high cost of veterinary medicines" (mean score: 49.28); "cattle feed and fodder are not available at subsidized rate" (mean score: 46.36); and non-availability of cheap, hybrid fodder seeds, fertilizers and other material at proper time (mean score: 42.58); were faced as $3^{\text {rd }}, 4^{\text {th }}$ and $5^{\text {th }}$ respectively.

\section{Administrative constraints}

The Table 5 clearly revealed that, the most important administrative constraint as faced by the beneficiaries was "complicated procedures to get loan, subsidy and other benefits" (mean score: 53.10); ranked first followed by "delay in payment of milk" (mean score: 52.67); "concerned officials are not interested to visit the area and conducting regular meeting with beneficiaries" (mean score: 50.03); "noncooperation of bank officials" (mean score: 48.38); and biasness in selecting beneficiaries and formation of groups (mean score: 50.03) were faced as second, third, fourth and fifth respectively administrative constraints by the beneficiaries.

The finding regarding "complicated procedures to get loan, subsidy and other benefits" are supported by Indumathi and Palanivelu (2013),

Who had reported that $50 \%$ of the respondents were not satisfied with the bankers, while finding regarding "concerned officials are not interested to visit the area and conducting regular meeting" is in line with the findings of Singh (2006) and Tiwari et al., (2003).

\section{Socio psychological constraints}

Among the technical constraints (Table 6), "lack of risk bearing capacity among the members" (mean score: 58.83) was the most serious constraint faced by the beneficiaries. "Lack of democratic awareness, harmony and participation among group members" (mean score: 56.64); "lack of participation of members with various developmental organizations" (mean score: 50.72); "preference for jobs rather than dairy based self-employment" (mean score: 43.53); and resource full / progressive people of the village discouraging the members to join the group (mean score: 38.25) were faced as second, third, fourth and fifth important constraints respectively by the beneficiaries.

\section{Marketing constraints}

Results regarding marketing constraints (Table 7 ) indicated that the constraint "Un-organized marketing" (mean score: 64.12) was ranked first by the members of SHG in the study area; as they were mostly selling their products through milk vendors.

Hence it is suggested that there should be improved marketing system, so that milk producers could get higher prices of milk. "Lack of consumer support" (mean score: 63.44); and Irregular demand of product (mean score: 61.78) has been found to be the second and third most serious constraint regarding the marketing of products.

The other constraints such as "lack of marketing skills" (mean score: 59.73); "distant markets" (mean score: 59.00); "lack of adequate price of the value added products" (mean score: 57.15); "high packaging cost" (mean score: 49.43); "lack of advertisement" (mean score: 41.16); "less time available for sale of product" (mean score: 40.73); "lack of government support" (mean score: 40.29); "competition among fellow SHGs" (mean score: 36.61); and "insufficient knowledge regarding marketing policy" (mean score: 25.92 ) were ranked $4^{\text {th }}, 5^{\text {th }}$, $6^{\text {th }}, 7^{\text {th }}, 8^{\text {th }} 9^{\text {th }}, 10^{\text {th }}, 11^{\text {th }}$ and $12^{\text {th }}$ respectively by the beneficiaries on the basis of their mean score.

The study reflects that the major constraints faced by the beneficiaries of SHGs were low proper price of milk, lack of proper knowledge about purchase of good quantity of feed, fodder and milch animals, problem in taking group decision, lack of trained, field oriented and experienced staff at village level, lack of proper 
technical guidance and advice, high cost of cattle feed and mineral mixture, complicated procedures to get loan, subsidy and other benefits, lack of risk bearing capacity among the members, un-organized marketing, lack of marketing skills, irregular demand of product etc. Hence, for smooth functioning of livestock based SHGs in sustainable manner there is awful need to eliminate these constraints on priority basis with the considerable focus on the need and interests of the beneficiaries. The above problems can be solved by taking into account various strategies like increasing educational opportunity among women, providing training facilities at village level, giving financial assistance, market facilities, subsidies, organizing workshops, etc. There is need to provide a bigger platform to the SHGs to market their products. The attention of policy makers is needed for more interaction among the beneficiaries and officials, promotion of aggressive extension activities for awareness and capacity building of livestock based SHGs. Therefore, there is a need for the extension workers, researchers and technologists to provide a helping hand to them.

\section{Acknowledgement}

Vice Chancellor, Guru Angad Dev Veterinary and Animal Sciences University, Ludhiana, Punjab for providing all necessary facilities and help in connection with this research wok. Support from officials of Verka milk co- operative society Ludhiana, SACH (Society for action in community health) NGO officials, Director ATMA Ludhiana, NRLM officials, Ludhiana is duly acknowledged.

\section{References}

Indumathi C, Palanivelu P. 2013. Women empowerment through Self Help Groups. Global Research Analysis 2 (6), 27-30.

Jain R, and Kushawala R K. 2004. Self-help groups- Issues and Constraints. Indian J. Ext. Edn., XXXX (3/4).

Singh U 2006. Multidimensional impact of women dairy cooperative societies on beneficiaries in Haryana, Ph.D. Thesis, National Dairy Research Institute, Deemed University, Karnal, Haryana, India.

Tiwari R K, Bisen J P and Sharma P N. 2003. A study on constraints and suggestions regarding adoption of improved animal husbandry practices in Chhattisgarh Plains. Indian Res. J. Ext. Edu. 3 (1): 2229.

Varathan Jaya B, Prabu M A, Pandian Saravana Serma, Kumar Senthil $G$ and Kumar Selva N K. 2012. Production and marketing constraints in dairy cattle rearing as perceived by women self-help group members and non-members. Tamilnadu J. Veterinary \& Animal Sciences 8 (2) 68-71.

\section{How to cite this article:}

Akshita Chadda, Y.S. Jadoun, S.K. Kansal, H.K. Verma and Bharti. 2019. Constraints Perceived By Beneficiaries of Livestock Based Self Help Groups (SHGs). Int.J.Curr.Microbiol.App.Sci. 8(07): 2661-2667. doi: https://doi.org/10.20546/ijcmas.2019.807.328 